\title{
The Capabilities of Sports Education Teachers in Making Character Oriented Lesson Plans and Learning Practices
}

\author{
Dimyati \\ Faculty of Sports Sciences \\ Universitas Negeri Yogyakarta \\ Yogyakarta, Indonesia \\ dimyati@uny.ac.id \\ Ermawan \\ Faculty of Sports Sciences \\ Universitas Negeri Yogyakarta \\ Yogyakarta, Indonesia \\ ermawan@uny.ac.id
}

\author{
Komarudin \\ Faculty of Sports Sciences \\ Universitas Negeri Yogyakarta \\ Yogyakarta, Indonesia \\ komarudin@uny.ac.id \\ Joko Purwanto \\ Faculty of Sports Sciences \\ Universitas Negeri Yogyakarta \\ Yogyakarta, Indonesia \\ joko_pur@uny.ac.id
}

\begin{abstract}
- this study is aimed at revealing the ability of Physical Education teachers to prepare the lesson plan and practice of learning (RPP) using character-oriented, teacherrelated beliefs. Character education and construction prototype is an effective model of physical education applied to form the character of students. This research uses a descriptive method and has been conducted using junior high school physical teachers in 50 schools throughout Yogyakarta city as the case study. Samples were taken randomly and 32 Physical Education teachers from 28 junior high schools were obtained. The procedure of data collection and analysis is in 2 stages, namely: (1) Identification of character charge on the entire Lesson Plan (RPP) which is quantitatively measured in percentage; and (2) The depth of the teacher's belief in character learning is revealed through a qualitative analysis process. The result of this research shows that: (1) The pedagogic competence of junior high school physical education teachers in Yogyakarta City in integrating character education which is manifested in the preparation of RPP is still low, that is only $28.1 \%$ of the teachers fully utilize character education element in preparing the character-oriented RPP; (2) The understanding of physical education teachers in relation to character study is relatively shallow and their mindset is less systemic and ; (3) The system of character study conducted by physical education teachers in SMP Kota Yogyakarta tends to be passive-internalization.
\end{abstract}

Keywords—teachers, physical education, learning, character

\section{INTRODUCTION}

The wave of improper behavior that hit the community is an integral part of the behavior of Indonesians today. The nature of the society seems to have been comprehended and realized by the Government. The Minister of Education and Culture, Prof. Dr. Muhammad Nuh, affirmed that the ambition of many parties is to fortify the education of character and culture in the nation. The government is resolute to fortify the nation's character and culture by means of education in schools [9].

Koesoema [8] states that in the educational system, there are enough instances of immoral behaviors exhibited by individuals ranging from students engaging in examination malpractices and plagiarizing the work of others without making references to the sources, to looking for ways to avoid carrying out tasks given out by the teacher. This situation shows that teachers who teach any subject should be concerned and emphasizes the significance of character education on students [10]. It is further stated by Lumpkin that schools and teachers assume greater roles and responsibilities in student learning, not only are they expected to meet expectations for student performance to succeed in the cognitive aspect but they must also emphasize the learning of affective aspects. In other words, an improvement in the affective aspect of the student or in the sense of character education should not be ignored.

The significance of building character through affective learning has been stressed in the aims and functions of the national competency standards of physical education as set out in the 2004 curriculum. Two of them state that the aims of physical education are: (1) To establish the foundation for a strong moral character through the internalization of values in Physical Education; and (2) To develop a sportive, honest, disciplined, responsible, co-operative, confident and democratic attitude through physical activity [4]. It is the obligation of the physical education teacher to help the student to realize the standard through affective learning. However, based on preliminary study through interviews held with the teachers of Physical Education in Elementary and Junior High Schools who continue the study from D-3 and D-2 to S1 in Physical Education Program Health and Recreation Faculty of Sport Sciences, Universitas Negeri Yogyakarta, they generally admit that they never gave affective lessons while giving Physical Education lessons at school.

The conditions stated above are ironic, because on the other hand, the teachers are aware that based on the curriculum, they are expected to teach affective aspects to the students, but in reality they are not taught. In other words, it can be said that respect for others, prosocial attitude, responsible attitude, honesty, discipline, fair deed and empathy which make up the affective aspect are expected to be taught by the teachers of physical education but are not taught. 
On the basis of the background of the problem as mentioned above, this research will try to provide answers to the following questions: (1) how is the pedagogical competence of the Physical Education teachers reflected in the ability to prepare the character-oriented lesson plan? (2) How is the understanding of the Physical Education teacher related to the learning of character to the learners? and (3) How is the character-learning practice conducted by the Physical Education teacher at school?

\section{Research Methodology}

The aims of this research are: (1) To obtain information related to pedagogical competence of Physical Education teachers reflected in the ability to prepare character-oriented lesson plans; (2) To gain a depiction of the Physical Education teacher's understanding related to character learning to learners; and (3) To reveal the characteristic teaching practices undertaken by teachers of Physical Education in schools so far. To achieve this goal, the researchers used a descriptive method involving junior high school teachers of Physical Education in 50 schools throughout Yogyakarta. Samples were taken randomly and 32 teachers of Physical Education came from 28 junior high schools. The process of data collection and analysis procedure consisted of 2 stages, namely (1) identification of character charge on the entire Lesson Plan (RPP) which is quantitatively measured by percentage; and (2) the depth of the teacher's belief in character learning is revealed through a qualitative analysis process.

\section{RESULTS}

By using the research method, the results obtained are as follows:

\section{A. Pedagogic Competencies of Physical Education Teachers}

Pedagogic competence here is defined as the ability of teachers to plan character-based learning. Learning planning can be seen from the Lesson Plan (RPP) made by the teacher. The RPP identified the content of its character, i.e. in purpose, process, and evaluation. The result of the data analysis conducted on 32 sample RPP shows that the pedagogic ability of junior high school teachers in Yogyakarta City in incorporating character education element in preparing RPP on goal, process and evaluation aspect is presented in the following table.

TABLE I. PedagogicAl Ability of PhysicAl EducAtion TEACHERS

\begin{tabular}{|c|c|c|c|}
\hline \multirow{3}{*}{ No } & \multicolumn{3}{|c|}{$\begin{array}{c}\text { "Character" Elemental Skills In RPP: Objectives, } \\
\text { Processes and Evaluations }\end{array}$} \\
\hline & \multicolumn{3}{|c|}{$\begin{array}{ll}\text { Frequency }(N=32) \\
\end{array}$} \\
\hline & & $\boldsymbol{F}$ & $\%$ \\
\hline 1 & In 3 Aspects (Complete) & 9 & 28,1 \\
\hline 2 & There are 2 Aspects & 13 & 40,6 \\
\hline 3 & There is one Aspect only & 7 & 21,9 \\
\hline 4 & None at all & 3 & 9,4 \\
\hline & Total: & 32 & 100,00 \\
\hline
\end{tabular}

Visually it can be seen in the diagram as illustrated below.

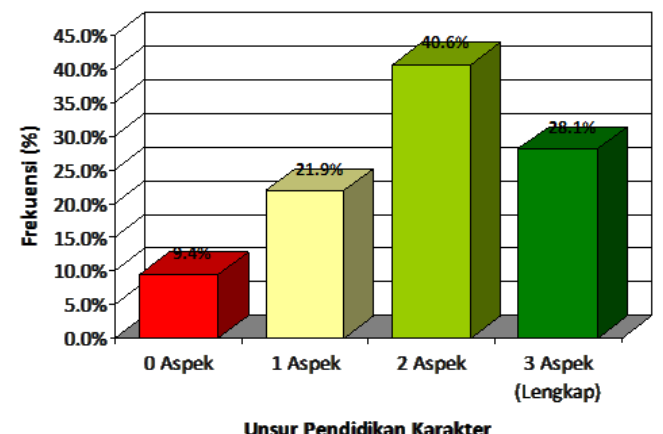

Fig. 1. Pedagogical Ability of Physical Education Teachers in Incorporating Character Education in RPP Preparation

Based on the tables and data above, it is known that out of 32 junior high school teachers in Yogyakarta, there are 9 (28.1\%) teachers incorporating character education elements in the preparation of RPP; the remaining $13(40.6 \%)$ teachers put are into two groups, 7 (21.9\%) teachers include it in only one aspect; and $3(9.4 \%)$ did not include any element of character education in RPP either in purpose, process, or evaluation.

\section{B. The Understanding of the Physical Education Teacher about Character Learning}

The teacher's understanding of Character Learning, which is explained as the perception, view, and knowledge possessed by the teacher in relation with the establishment of student character through physical education. From a number of teachers interviewed the phrases can be summarized as follows:

Teachers understand that as technology advances, the character of the party is declining; it cannot be denied that the progression of science and technology influences the behaviour of the students. With the freedom on cyber media, it is easy for children to get information, including inappropriate images.

Character education is better understood as courtesy such as etiquettes and dressing. There is a rather shallow understanding of the character of the teachers. Character is perceived as a matter of etiquette concerning manners and dressing. If a child is inappropriately dressed, such a child is considered to have no character. Likewise if a student does not bend while walking past the teacher, the student is considered to have no character.

What we normally experience is that the character of children nowadays is inappropriate especially their attitude towards their parents, their attitude towards the teacherand the way they mingle in the society, their characters have deteriorated. For example, while talking to elders, these children behave like they're talking to their friends. The second is their attitude towards their teachers. They seem ignorant. It cannot be judged from their age but from the way they speak.

Teachers are reluctant to handle students because of human rights, violence is considered an efficient means of instilling character. Because the society is aware of respect for human rights, parents tend to demand for schools to treat their children well. Parents will complain and may even sue the 
school when their children are treated violently. In many situations, sports teachers punish students who are considered naughty and sometimes, these punishments include some violence.

Character education handling is not by design, but by accident; The learning of physical education is understood by the teacher. More as an instrument to teach motion or sport alone. Therefore, the character charge is never taught deliberately. Handling that is considered a character education when a child makes a mistake, then the child is advised, scolded, and if necessary, punished physically.

Parents are mostly involved only because their children have problems, which they are sometimes called to the school to attend to. Character education cannot be restricted to the school environment, but needs to be involved in other aspects of life such as the family. In terms of time, the children spend only about 5 hours in school daily, and they spend the rest which is greater than 5 hours with their families or in the society. Parental involvement needs to be initiated early in a planned manner, not just involved when the child is in trouble. The latter is what many schools do

\section{Character Learning Practices by Physical Education Teacher}

Physical education tends to be understood as an instrument used to inculcate discipline. The discipline aspect is an important part of physical education learning, but it should be remembered that the end result of learning is not only discipline, but also honesty, respect for others, obedience to the rules, and so forth.

In terms of learning practices, this is meant as a tangible form of learning process conducted by physical education teachers, ranging from start-up (warming-up), core learning, and cooling-down. From the analysis conducted on three video recordings in three schools, namely: SMP $\mathrm{N} 8$ Yogyakarta, SMP IT Masjid Syuhada Yogyakarta, and SMP Stella Duce, the following were revealed: (1) At the beginning of learning, teachers give an explanation of the subject matter to their students, followed by a warm-up process involving stretching and running around the field; (2) Submission of learning substance focuses on the mastery of sports skills. The values contained in the activity are not taught to learners: (3) By the time the lesson ends, the teacher tends to dissolve the group without reflection on the learning that has just been done.

\section{DISCUSSION}

The results showed that the pedagogical competence of Physical Education teachers in SMP Yogyakarta City in integrating character education manifested in the preparation of RPP is still low. This phenomenon is inseparable from the culture of education, especially at primary and secondary levels. Schools, teachers, tutors and even parents are stuffing their students with the test questions and national exam preparation (UN). The only goal is for the students to pass in flying colours [1]. With this moral pattern, character education is neglected. Teachers, including teachers of Physical Education fail to teach the values of respect, prosocial attitude, responsible attitude, honesty, discipline, fair dealing and empathy which is the essence of the students' character-forming values. Automatically all this has a part to play in the teacher's low ability to prepare teachers' preparation plans (RPP) including physical education teachers.

On the other hand, the results of the study also show that the understanding of physical education teachers related to the learning of characters is relatively narrow with less systematic thinking. Doty [5] says that the exercise experience can determine the values of the character, then the environmental factors in this case the trainer or teacher needs to have the aim to develop character values. But the study shows that "many coaches work without any reference to a coaching process model and, alternatively, their base on practice, intuitions, events and previous experience" [3]. Hellison [11] asserts: "A major problem in this program is the attempt to use the professional sports model to build character in youth". Thus, it becomes expected that the teachers of Physical Education are shallow in the knowledge of character-valueslearning. Hatten, et al [7] asserts that the major problem in Physical Education and sport today is that very few physical education teachers and trainers teach ethical proper to their students.

The results of a different study also found that: "The practice of character learning by physical education teachers in SMP Kota Yogyakarta tends to be passive-internalization. The formation of characters is considered to have occurred when the child engaged in sports activities, without having construction within the cognitive structure of children ". This inaccurate understanding is deeply disliked given the moral behaviour attained through social interaction, the ways in which relationships with others are built and facilitated influences ethical and moral behaviour which are acquired through physical education. In other words, values and ethics can be promoted and passed to children who take part in sports and physical education through the inculcation of the moral character of trainers / sports teachers. Although study shows that moral thought or the ability to reflect on moral issues and the maturity level of an athlete's moral reasoning is low, there is also proof that coaches and sports teachers can foster and develop moral reasoning if they actively strive to do so [12]. Thus physical education has an efficient ability to promote moral development, so far as the social interactions associated with psychological engagement in sports can influence specific traits that can serve as a foundation for moral decision making [6]. It can all happen if the teachers of physical education have the intention and are active in teaching the character values so that the child is built in his cognitive structure which can be moulded by the physical education teachers.

\section{CONCLUSION}

Based on the results of the research and discussion stated above, it can be concluded as follows:

1. Pedagogic competence of Junior High School Physical education teachers in Yogyakarta City in integrating character education embodied in the formation of Lesson Plans (RPP) is still low, only $28.1 \%$ of the teachers use elements of character education in the preparation of RPP.

2. The physical education teachers have a shallow understanding of character study with a less systematic mindset.

- Character education is better understood as a courtesy such as etiquette and how to dres 
- The teachers are reluctant to handle students because of human rights, violence is considered an effective way of instilling character;

- Character education handling is not by design, but by accident;

- Parents are only involved when their children have problems and they are called to school.

- Physical education tends to be comprehended as a means of inculcating discipline.

3. The method of character study implimented by physical education teachers in junior high schools throughout the city of Yogyakarta tends to be passive-internalization. Character formation is considered to have occurred when the child is involved in sports activities, without having a construction within the cognitive structure of the child.

\section{REFERENCES}

[1] Antarina S.F Amir, http://edukasi.kompas.com/read/2010/01/20/18533116/UN.Vs.Peridika n.Karakter..Pilih.Mana. Retrieved, Wednesday, January 20, 2010.

[2] Canadian Center for Ethics in Sport (CCES). Canadian Public Opinion Survey on Youth and Sport. Ottawa. 2002

[3] Cushion, J. Christopher, Armor, M. Kathleen, and R. L. Jones, "Locating The Coaching Process In Practice: The 'For' And 'Of' Coaching Model," Physical Education and Sport Pedagogy, Vol. 11, No. 1, February 2006, pp. 83-99. 2006.

[4] Ministry of Education. Curriculum 2004, Standard of Competency Subject of Physical Education Elementary School and Madrasah Ibtidaiyah. Jakarta: Depdiknas. 2003.

[5] J. Doty, "Sport Built Character?!," Journal of College \& Character, 2006. Vol. VII, No. 3, April 2006, pp. 2-9.

[6] Ewing, M, L, Gano -Overway, C. Branta \& V. Seefeldt. "The Role of Sports in Youth Development." In M. Gatz, M. Messner \& S. BallRokeach (eds.), Paradoxes of Youth and Sport (Albany: State University of New York Press, 31-47). 2002.

[7] Hatten, Timothy. Docheff, Dennis. Lynch, Loren E, \& Foy, Sandra. Can Physical Educators Do More To Teach Ethical Behavior And Sports? Journal and Physical Education, Recreation and Dance, My / Jun 2001: 72, 5; Research Library. 2001.

[8] Koesoema, A. Doni, Character Educators in the Keblinger Period. Jakarta: Publisher Grasindo School. 2009.

[9] Kompas, Friday, January 15, 2010. Education Ignores Character. Page 12.

[10]A. Lumpkin, Teacher as Role Models Teaching Character and Moral Virtues. Journal of Physical Education Recreation and Dance. 79, 2. pg. 45. 2008 .

[11]Tom. Martinek, Compassionate and Caring Leadership in Underserved Adolescents through Sport. Paper, presented in, International Conference on Sport and Sustainable Development, Yogyakarta, Indonesia, September 2003.

[12]PCPFS. President's Council on Physical Fitness and Sport. Sports and Character Development, President's Council on Physical Fitness and Sports. Washington, DC: 2006.

[13] V. Seefeldt, \& M. Ewing, "Youth Sports in America: An Overview," President's Council on Physical Fitness and Sport Research Digest 2. 2002. 